\title{
Abstracts and Biographies
}



Thomas Bartscherer, PaOLo D'Iorio,

Philosophy in an Evolving Web: Necessary Conditions, Web Technologies, and the Discovery Project

This article considers how digital technology — and in particular recent innovations in networking and Semantic Web - can be exploited to assist scholars in conducting academic research while at the same time minimizing the risks posed by web-mediated scholarship. We argue that an clear understanding of how humanities scholarship has traditionally been structured and practiced is a prerequisite for the success of any large-scale digital humanities initiative, and we therefore attempt to articulate what we have identified as the conditions necessary for the possibility of scholarship, conditions which are independent of any given technology. We discuss the following five conditions: stability, accessibility, durability, dissemination, and standards of quality. We then turn to a detailed look at the Discovery Project, recently launched under the aegis of the European Union's eContentplus programme, to consider if and how the project meets the conditions specified. We conclude by noting three major challenges that confront this project and all similar initiatives aimed at integrating humanities research and digital technology.

Thomas Bartscherer is completing a doctoral thesis at the University of Chicago's Committee on Social Thought and is Associate Director of the Language and Thinking program at Bard College in New York, where he also teaches in the Humanities. He is co-editor of Switching Codes, a collection of essays on the impact of digital technology on thought and practice in the arts and the humanities (University of Chicago Press, forthcoming) and has co-edited Erotikon: Essay on Eros, Ancient and Modern (University of Chicago Press, 2005). Bartscherer holds an MA from the University of Chicago and a BA from the University of Pennsylvania. He has been a Visiting Scholar at the École Normale Supérieure (2001-03) and the University of Heidelberg (1997-99). He is a research associate with the eContentplus project Discovery.

Dr. PaOlo D'Iorio is senior research scholar at the Institut des Textes et Manuscrits Modernes (CNRS-ENS, Paris) and research associate at the Oxford Internet Institute and at the Maison Maison Française d'Oxford. In recent years he has held a major Humboldt foundation fellowship at the University of Munich, where he directed the HyperNietzsche Project. He is now coor- 
dinator of two European initiatives whose common goal is to establish an infrastructure for humanities scholarship on the Internet: the COST Action "Open Scholarly Communities on the Web" and the eContentplus project "Discovery. Digital semantic corpora for virtual research in philosophy".

\section{CHRIS CHESHER,}

\section{Binding time: Harold Innis and the balance of new media}

This paper evaluates how Harold Innis's 1950's theory of communication can help to understand the 21 st century world dominated by digital media. For Innis, how media of an era relate to time and space helps define the civilisation: in its materials, languages and social relationships. Space-binding media (such as papyrus, or electronic communication) facilitate command and control over territory, supporting empire-building. Time-binding media (such as stone, and spoken communication), on the other hand, operate to maintain cultural continuity, and tend towards more stately priestly structures.

The computer, as the dominant medium of the current era, tends to generate distinctive relationships with time and space (without simply determining social outcomes). Digitality seems to efface media materiality, as software operates across proliferating networks of different materials: electronic, semiconducting, magnetic, optical and so on. However, materiality always returns. In line with Innis's warnings, the implementation of computers has always been out of balance. Command functions were always cheaper and more effective than memory or storage. Digital cultural artifacts are notoriously unstable, as physical media deteriorate, standards are superseded, and expertise is lost. At the same time, some configurations of new internet services such as chat, digital images, social networking and microblogging suggest new patterns in the formation and maintenance of cultural memory.

Chris Chesher is Director of the Digital Cultures program at the University of Sydney. From a background in media studies, his research has consistently been with new media, including recent work on mobile phones and everyday life; computer games and screen cultures; and the interplay between human and non-human language users on the internet. 


\section{GERHARD CLEMENZ,}

On our Knowledge of Markets for Knowledge-A Survey

It is commonplace that advanced economies are knowledge (based) economies, meaning that knowledge is a major factor for the creation of economic benefits. The importance of knowledge for economic development was emphasized a long time ago by leading "Austrian" economists like Joseph Schumpeter and Friedrich Hayek. Both contemporaries of Wittgenstein claimed that the superiority of a capitalist economy as compared to its alternatives stems from its efficiency with respect to the creation, processing and utilization of knowledge. But knowledge, however defined, is quite different in many respects from most other goods. Markets are fairly efficient when it comes to the allocation of conventional goods, but various difficulties and paradoxes arise when they are supposed to trade knowledge and provide incentives for its creation. We shall consider some of them and discuss whether alternative institutional setups after all may not be as bad as some Austrian economists maintained.

Gerhard Clemenz is currently full professor at the Department of Economics at the University of Vienna; Chairman of the Senate of the University of Vienna. Past president of the Austrian Economic Association and certified expert witness for cartel cases. Past positions include Full Professor of Economics at the University of Regensburg and Bundesbank Professor at the Free University of Berlin. Main current research interests include Industrial Organisation, research and development, vertical integration, competition policy. Numerous publications in international journals including International Economic Review, European Economic Review, Journal of Industrial Economics, Journal of International Economics, Scandinavian Journal of Economics etc.

CHARLES ESS,

East-West Perspectives on Privacy, Ethical Pluralism and Global Information Ethics

Information and Communication Technologies (ICTs) are both primary drivers and facilitating technologies of globalization - and thereby, of exponentially expanding possibilities of cross-cultural encounters. Such encoun- 
ters may foster greater communication and economic development: but they further risk evoking a Manichean dilemma between ethnocentric imperialism (i.e., the overt or covert imposition of our own cultural norms, values, and practices upon "the Other") and a fragmenting relativism (one inspired in part by the need for tolerance and the protection of cultural identity and diversity - but which further opens the field to those who would simply impose their own views by force). Discerning middle grounds between these Manichean polarities is a central task of an emerging global information and computing ethics (ICE).

I argue that we may discern and articulate the middle grounds required by a shared global ICE - first of all, by developing a critical self-awareness of how specific Western norms, values, and practices are embedded in ICTs themselves. I then turn to current discussion of conceptions of privacy and efforts at data privacy protection in both Western and Eastern contexts: these examples from praxis highlight a series of guidelines and approaches to the sorts of cross-cultural dialogues required for an ICE that establishes middle grounds between imperialism and relativism. Next, I highlight a number of recent theoretical developments in especially East-West dialogues regarding ICE - most importantly, an emerging virtue ethics that, as rooted in both Eastern and Western traditions, may serve as an important bridge between cultures that will thereby sustain an ICE that avoids imperialism and relativism. Finally, I elaborate on an ethical pluralism that emerges in conjunction with each of these elements: this pluralism seeks precisely to establish a middle ground between ethnocentric imperialism and fragmenting relativism by understanding shared norms and values as allowing for diverse interpretations / applications / and understandings - specifically, as mediated through phronesis, ethical judgment - that thereby reflect and preserve the distinctive norms and values defining specific cultures. Both at the levels of meta-theory and praxis (e.g., with regard to the issue of privacy), then, such ethical pluralism thus recommends itself as an important component of an emerging global ICE.

Charles Ess is Professor of Philosophy and Religion and Distinguished Professor of Interdisciplinary Studies, Drury University (Springfield, Missouri, USA); and Professor II, Programme for Applied Ethics, Norwegian University of Science and Technology (Trondheim). Dr. Ess has received awards for teaching excellence and scholarship, and published extensively in comparative (East-West) philosophy, applied ethics, discourse ethics, history of philosophy, feminist Biblical studies, and Computer-Mediated Communication (CMC). With Fay Sudweeks, Dr. Ess co-chairs the biennial conferences 
Cultural Attitudes towards Technology and Communication (CATaC). He has served as a Visiting Professor at IT-University, Copenhagen (2003), the Université de Nîmes (2007), and Aarhus University (2007), and as a Fulbright Senior Scholar, University of Trier (2004).

AUGUST FENK, $A$ view on the iconic turn from a semiotic perspective

The "iconic" or "pictorial turn" pulled along by the "digital turn" was sometimes considered rather a re-turn to preliterate societies. But, actually, the respective picture material is embedded in a mix of materials of diverse sense-modalities and symbolic modalities. From a cognitive perspective such materials may be viewed as those modules of an almost inexhaustible "external memory system" which now can be retrieved, linked and extended by its users. Some facets become apparent in a semiotic analysis of these modules: They deprive us from many "indexical" cues which might otherwise allow to directly assign them to concrete agents and intentions, places and points of time. And if the term iconicity is reserved for cases of similarity established by a subject's simulating (picturing, imitating, modelling ...) activities, all "automatic recordings", including the digital format, are noniconic. Paradoxically, they are at best iconic in cases of artificial reworks or forgeries.

August Fenk (b. 1945) studied Psychology and Physical Anthropology in Vienna and graduated there 1971 with an experimental dissertation on slow brain potentials in problem solving. Since 1973 at the University of Klagenfurt (Department of Media and Communication Studies) where he qualified 1980 for lecturing in Psychology with experimental studies on sensory storing in language processing. Contributions to cognitive psychology, quantitative linguistics, theoretical semiotics. After two terms of office as Chair of the Faculty of Humanities two sabbaticals: winter-semester 03/04 and summer-semester '05. Current research centers on statistical language universals and on cognitive and semiotic aspects of visualization. 
MAURIZIO FERRARIS,

Science of Recording

In 2006, all the newspaper published a document, proving that Gunter Grass was soldier of Waffen-SS. A sort of purloined letter in the sense of Poe, or, so to speak, a Leave of Grass. But this kind of use of documents will be increasingly powerful and widespread when the paper disappears, and traces, records and inscriptions of every sort appear in the internet age, and can be found by Google. How can we manage documents in a world characterized by the explosion of writing?

The problems related to privacy, constantly increasing in advanced societies, are usually interpreted in the light of the recurrent image of a Big Brother, that is, a big watching eye, according to the model of Bentham's Panopticon. On one hand, it's surely true that things like infrared viewers are nowadays widespread as well as cameras that constantly survey every aspect of our lives, in banks, stations, supermarkets, offices and private buildings. On the other hand, however, the power of this big eye would be useless without a registration, which is exactly what transforms a vision in a document. No doubt, the recent debates about phone interceptions are just the tip of an iceberg: the question we are facing here is an important one for democracy, and a complete grasp of the category of documentality (the social inscription of our life in the digital age) is required in order to get a satisfactory answer to it.

Maurizio Ferraris is professor of philosophy at the University of Turin, where he heads the Center for Theoretical and Applied Ontology (http:// www.ctaorg.org/), the Laboratory of Ontology (http://www.labont.it/), and is director of "Rivista di Estetica". Awarded with many literary and research prizes (fellow of the Humboldt Foundation and of the Italian Academy at the Columbia University, "Claretta" Prize, Valitutti Prize, Castiglioncello Philosophical Prize) he is the author of 32 books (among the most recents, "Goodbye Kant!", Milan 2004, "Dove sei? Ontologia del telefonino", Milan 2005, "Jackie Derrida", Turin 2006, "Babbo Natale, Gesù Adulto. In cosa crede chi crede?", Milan 2006) and more than 1.000 scientific articles. He is a regular contributor of the Sunday cultural extra of "Il Sole-24 ore", "La Stampa" (Turin) and "Il secolo XIX" (Genoa). A more extensive version of his curriculum, with a complete bibliography, descriptions and reviews of his works can be found at http://www.labont.it/ferraris/. 


\section{PETER FLEISSNER,}

Information Society: A second "Great Transformation"?

Usually one characterizes contemporary capitalism as acting on global markets, production dominated by transnational companies, with an important role of financial capital, and backed by neoliberal ideologies. But for an appropriate assessment of the emerging information society this is not sufficient. The author proposes to emphazize the economic content of the information society by two essentially new features: commodification and commercialisation of many areas of human activities. Culture, knowledge, arts, research, entertainment are globally conquered by the market.

Commodification and commercialisation have always ambiguous effects. While on the one hand Intellectual Property Rights and a technology of copy protection generate artificial shortage of the nowadays superfluous digital goods (because in principle they could be distributed nearly for free to everybody on the globe), commodification and commercialisation can also lead to new goods or services and a better quality of products.

This trend of commodification and commercialisation of human culture can be compared by extension and importance to the commercialisation of work during the first half of the 19th century in England which was described by Karl Polanyi in his well known book „The Great Transformation“ (1944). There he located the basic transformation of a capitalistic economy into a capitalistic society.

Peter Fleissner, born 1944, since 1962 living in Vienna, retired October 2006 from his chair on Design and Assessment of New Technologies, which he held at the University of Technology in Vienna, Austria, since 1990, after seven years of work as a temporary agent for the European Union (19972000 Head of the Department "Technology, Employment, Competitiveness and Society" of the Seville based Institute for Prospective Technological Studies of the Joint Research Centre of the European Commission in Spain; 2000-2004 Head of the Department "Research and Networking" of the European Monitoring Centre on Racism and Xenophobia). Before, he had worked for the Austrian Academy of Sciences, for the International Institute for Applied Systems Analysis, Laxenburg, Austria, as a research scholar at MIT (Massachusetts Institute of Technology) and at the Institute for Advanced Studies, Vienna, Austria.

He is elected Member of the Leibniz-Sozietät, Berlin, Germany, and was a Member of the Board of Directors of the research institute of the Black Sea 
Economic Association (ICBSS), in Athens, Greece, and of the Advisory Board of the recently founded United Nations University/College of Europe (Bruges, Belgium). He has worked as a consultant for Siemens, Munich, for ORF (Austrian Radio and Television), for the Science Center, Berlin, for the Institute for Systems Technology and Innovation Research, ISI, Karlsruhe, for the Austrian Chamber of Labour, and for the Austrian Association of Industrialists. He is the (co)author of more than 15 books and of hundreds of book chapters and articles in scientific journals and research reports. For a complete list of publications and activities see: http://www.arrakis. es/ fleissner

\section{NiELS GotTSCHALK-MAZOUZ:}

Internet and the flow of knowledge: Which ethical and political challenges will we face?

The classic philosophical definition of knowledge does not address important features of the kind of knowledge that is central in the so-called knowledge societies, or so is argued here. Therefore a different conceptual approach is proposed that combines and interprets typical features of knowledge that have been expressed in a range of disciplines, including sociology, economics, psychology and information science. Using this approach, the kind of knowledge is examined that is provided through the internet. I characterise it as representative and consisting of chunks of "knowledge candidates," for it has to be recognised as knowledge on an individual basis and because institutional recognition is mostly absent, and I discuss some core ethical and political challenges of this. In doing so, recent or planned innovations are considered (Web 2.0, Semantic Web, Ubiquitous Computing). With respect to the flow of knowledge and the types of knowledge that constitute this flow, it is argued that these innovations might interact in a way that would intensify the propagation of candidates of, what has traditionally been referred to as, know-how, embodied in machines as parts of man-machine systems. If this prospect is plausible, then further struggles will focus on surveillance and, finally, control of the actual functioning of such systems. That is to say, these struggles will finally be on what you can (or cannot) do, and thus on power. Following this hypothesis, the main ethical and political challenges in these struggles are seen as those that are typical for power issues. 
Dr. Niels Gottschalk-Mazouz is Wissenschaftlicher Assistent at the Universität Stuttgart. He studied physics, philosophy and history of science in Berlin, Leipzig and Tübingen and graduated at the Technische Universität Berlin (Dipl.Phys., 1995). He joined the philosophy faculty of the Universität Stuttgart in 1997, where he obtained his doctorate in 1999 with a thesis on discourse ethics and his habilitation in 2006 with a thesis on concepts of knowledge.

His research has covered a variety of subjects in applied ethics, political philosophy and philosophy of technology, including interdisciplinary work on energy, environment, healthcare, and ICT. More information and a list of publications is available at http://www.uni-stuttgart.de/philo/index.php?ngm

STEFAN GRADMANN,

Some thoughts on the importance of Open Source and Open Access for an emerging digital scholarship

Both constituents of the term 'Open Access' are of equal and vital importance for innovative scholarship to work effectively in a networked digital setting. ,Access ' in such a context implies much more than just being able to freely read scholarly sources: the freedom to process and reaggregate such sources must also be part of such a setting (while fully respecting source authenticity and integrity). 'Open', as well, has at least three distinct connotations here: (1) absence of economic and legal barriers for access on the WWW, (2) availability of scholarly sources in open, transparent and non proprietary formats, (3) the processing methods to be used for processing sources should themselves be implemented as open source software.

The presentation will explore all three aspects of 'openness' but will put particular stress on the issue of open document formats and models as well as on the reasons for open source based approaches being appropriate for effective scholarly work in the e-humanities. Economic considerations as well as the need to retain control of processing methods are considered in this context together with the implicate responsibilities such a strategy creates for an open source based community of scholarship in philosophy.

Dr. Stefan Gradmann, Professor of Library and Information Science at Humboldt-University in Berlin with a focus on knowledge management and semantics based operations. He studied Greek, philosophy and German literature in Paris and Freiburg (Brsg.) and received a Ph.D in Freiburg in 
1986. After additional training in scientific librarianship (Cologne, 19871988) he worked as scientific librarian at the State and University Library in Hamburg from 1988-1992. From 1992-1997 he was the director of the GBV Library Network. 1997-2000 he was employed by Pica B.V. in Leiden as product manager and senior consultant. Form 2000 to March 2008, he was Deputy Director of the University of Hamburg Regional Computing Center. He was the Project Director of the GAP (German Academic Publishers) Project of the German Research Association and technical co-ordinator of the EC funded FIGARO project. Stefan has numerous European and international contacts in the areas of open access publishing and humanities computing. He was an international advisor for the ACLS Commission on Cyberinfrastructure for the Humanities and Social Sciences and as such has contributed to the report "Our Cultural Commonwealth" (http://www.acls. org/cyberinfrastructure/OurCulturalCommonwealth.pdf) Stefan currently is heavily involved in building Europeana, the European Digital Library, and more specifically is leading WP2 on technical and semantic interoperability as part of the EDLnet project .

FRANK HARTMANN,

Weltkommunikation und World Brain.

Zur Archäologie der Informationsgesellschaft

$\mathrm{Zu}$ den herausragenden mentalen Effekten der bereits Mitte des 19. Jahrhunderts einsetzenden Globalisierung zählt die Tatsache, dass Unwahrscheinlichkeiten wie die Telekommunikation den in Termini des Transports bestimmten Raum neu definieren. Das Netz der Telegraphenkommunikation wird an jenen Punkten geknüpft, die in merkantiler Hinsicht am interessantesten sind. An solchen Knotenpunkten hängenauch heute noch die Datenströme der modernen Lebensform, an ihnen wurde verkehrs- und nachrichtentechnisch »eine Welt geknüpft und zusammengezogen, die es vorher nicht gegeben hatte.« (Karl Schlögel)

Um welche Infrastruktur handelte es sich dabei? Diese Frage wurde überrraschenderweise auch philosophisch gestellt. Die neuen Technologien konnten nicht mehr in der Begrifflichkeit der Werkzeug-Technik gefaßt werden. So taucht im frühen Mediendiskurs - avant la lettre - die Idee der Organprojektion auf, und eine neue Philosophie der Technik widmet sich den kognitiven Implikationen der neueren Entwicklungen, deren Tenor bereits erstaunlich dem des Theorie-Begleitdiskurses zum Internet gleicht. Mit 
Ernst Kapp untersucht der Vortrag den exzentrischen Vertreter einer neuen Philosophie der Technik, deren Motive auf Medieneffekte gerichtet waren, wie sie in der akademischen Philosophie bis vor kurzem noch systematisch unterschlagen wurden.

Frank Hartmann, Univ.-Doz. Dr. habil., lebt in Wien - Studium der Philosophie, Soziologie, Kunstgeschichte sowie der Publizistik- und Kommunikationswissenschaft an der Universität Wien, 1987 Promotion am Institut für Philosophie ebd.; 2000 Habilitation und seither Universitätsdozent (nicht beamtet) für Medien- und Kommunikationstheorie an der Universität Wien, Lehrbeauftragter im Fachbereich Kommunikationswissenschaft der Universität Salzburg, Gastprofessor an der philosophischen Fakultät der Universität Erfurt (2007).

Gewerbliche Tätigkeit als Autor, Wissenschaftsjournalist, PR- und Medienberater. Arbeits- und Publikationsschwerpunkte: Medienphilosophie, Mediengeschichte mit Schwerpunkt visuelle Kommunikation.

Publikationen (Auswahl): Medien und Kommunikation (Wien: facultas wuv/UTB 2008), Globale Medienkultur. Geschichte und Theorien (Wien: facultas wuv /UTB 2006, 2. Auflage), Bildersprache. Otto Neurath, Visualisierungen (mit Erwin K. Bauer, Wien: WUV 2006), Mediologie. Ansätze einer Medientheorie der Kulturwissenschaften (Wien: WUV 2003), Medienphilosophie (Wien: WUV/UTB 2000), Cyber-Philosophie. Medientheoretische Auslotungen (Wien: Passagen 1999, 2. Auflage) Internet: www. medienphilosophie.net. E-mail: frank.hartmann@univie.ac.at

\section{MICHAEL HEIM,}

Avatars und Lebensform: Kirchberg 2007

The avatar is a pointer to human presence on computer networks but it is also a phantom of future transnational communities. The first half of this paper scans initiatives in avatar research - a journey from promise to frustration. Experiments suggest that virtual-worlds technology holds promise for transnational empathy, beyond fi rst-person point-of-view, which might someday ease confl icts between nations. But the unfulfilled promise reveals a disconnect between technological evolution and human empathy. The second half of the paper shifts to educational practices that might support trans-socializing technology. Reviving cultural artifactslike poetry, music, and drama, the interdisciplinary humanities might increase the likelihood of 
imaginatively adopting another's perspective. The discussion and emulation of art works may belong to the future of avatars.

Michael R. Heim is the author of several books including The Metaphysics of Virtual Reality (Oxford, 1993), Virtual Realism (Oxford, 1998), and Electric Language: A Philosophical Study of Word Processing (Yale, 1985, 1999). His books have been translated into several languages. He was recently contributing collaborator for the award-winning Austrian Zukunftsmagazin ,..copy“ and during the 1990s he organized six national conferences in Washington, DC for the Data Processing Management Association. At Art Center College of Design in Pasadena, California, he pioneered the use of 3D virtual worlds (cyberforum@artcenter), and in 2001 he held the first cross-campus Digital Cultures Fellowship from the University of California. He currently lectures in Humanities at the University of California at Irvine. His website is: www.mheim.com.

THEO HUG,

Medienphilosophie und BildungsphilosophieEin Plädoyer für Schnittstellenerkundungen

Anders als das Verhältnis von Bildungsphilosophie und Bildungsforschung ist jenes von Medien- und Bildungsphilosophie bislang weitgehend ein Desiderat geblieben. Das ist insofern erstaunlich, als in den letzten Jahren sowohl in der Medienphilosophie als auch in der Bildungsphilosophie der optionale Bereichscharakter der Medien in Frage gestellt worden ist. Dies kommt einerseits in der Rede von der „medialen Wende“ zum Ausdruck, die auf einer meta-theoretischen Ebene eine Alternative und Ergänzung der etablierten Paradigmen meint und die sich in Analogie zu bekannten Fokussierungen auf Sprache (linguistic turn), Kognition (cognitive turn), Zeichen (semiotic turn) oder Bilder (pictural turn, iconic turn) durch eine Konzentration auf Medien, Medialität und Medialisierung auszeichnet. Auf einer empirischen Ebene wird die Bedeutung der Medien für Prozesse der Kommunikation, des Wissensaufbaus und der Wirklichkeitskonstruktion hervorgehoben. Der Ausdruck „Medialisierung der Lebenswelten“ beinhaltet gewissermaßen beide Aspekte: Die erfahrbare Alltagswelt und Beobachtungen der „Mediendurchdringung“ sowie die Unhintergehbarkeit medialisierter Welten und deren Funktion als Ausgangspunkte für unsere Erkenntnisbestrebungen. Andererseits werden in der Bildungsphilosophie Fragen nach 
der Bedeutung der Medien in Bildungsprozessen und nach dem Stellenwert von Medienbildung zunehmend relevant.

Ausgehend von der Rekonstruktion unterschiedlicher Versionen und Konzeptionen der ,medialen Wende“" werden im Vortrag einige Schnittstellen neuerer bildungs- und medienphilosophischer Diskursstränge erkundet.

Theo Hug, Dr. phil., is associate professor of educational sciences at the University of Innsbruck and coordinator of the Innsbruck Media Studies research group. His areas of interest include media education and media literacy, e-education and microlearning, theory of knowledge and philosophy of science. He is particularly interested in interfaces of medialization and knowledge dynamics as well as learning processes. Some of his recent work is focussing on instant knowledge, bricolage and didactics of microlearning.

CAMERON MCEWEN,

The Necessary Multiplicity

The later Wittgenstein was certainly a pluralist. But there are many different pluralisms. With particular reference to recollections of Wittgenstein from Rush Rhees and Maurice O'Connor Drury, the guess is made that the later Wittgenstein's plurality was ontological and digital. The later work therefore continued and refined the Tractarian positions that the foundation of the world is not singular and that the relation of worlds as based on these plural foundations is digital, not analog. But just as Wittgenstein himself came to this position in a way which was not purely digital (otherwise he would already have known what he despaired of finding), so the relation of the analog to the digital had to be rethought in the latter work in order to account for such achievements as language acquisition. At the same time, this allowed Wittgenstein to illustrate and to teach that method of persistent questioning and repeated re-starting through which he himself had come to discover his calling.

Cameron McEwen is a partner in the electronic publisher InteLex (http:// www.nlx.com/). His research interests include Wittgenstein and Heidegger and are generally dedicated to an understanding of the history and implications of ontological plurality (Plato's "gigantomachia"). 
MICHAEL NENTWICH, Will the Open Access Movement be successful?

No doubt that from the point of view of scholars around the world, Open Access seems to be the obvious solution to the evident problems of scholarly publishing in the present age of commodification. Access to the academic literature would be universally available and hence not restricted to those lucky enough to belong to wealthy institutions that are able to afford all the subscriptions necessary. Furthermore, many believe that only if we have a fully digital, openly accessible archive of the relevant literature, enhanced with overlay functions such as commenting, reviewing and intelligent quality filtering, we will be able to overcome restrictions of the present, paperbased scholarly communication system.

Many initiatives have been launched (e.g. the Berlin Declaration), some funding agencies have already reacted by adopting Open Access policies (notably the British Wellcome Trust, but also the German DFG or the Austrian FWF), new journal models are being tested to prove that Open Access is a viable economic model (e.g. BioMedCentral), Open Access self-archiving servers flourish around the world (not least in philosophy) and even high politics has reacted (most recently the European Commission). But still, after a decade or so of initiatives, testing and promoting only a tiny fraction of the available scientific literature is Open Access. It is growing, no doubt, but we are a long way from universal open access.

So, will the Open Access movement be successful? Or, put differently, can it be successful? What are the chances that the incumbents - the big commercial (as well as the not-for-profit, associational) publishing industry-will give way to a de-commodified future? Is there a middle-ground where all the players and interests could meet? This paper will contribute to this open debate by analysing recent trends and weighting the arguments put forward in this heated debate.

Michael Nentwich - Studium der Handelswissenschaften an der Wirtschaftsunversität Wien sowie der Politikwissenschaft und Rechtswissenschaften an der Universität Wien, Sponsion zum Mag.iur 1988; Promotion zum Dr. jur. 1995. 1990-92 wiss. Mitarbeiter am ITA (Institut für Technikfolgenabschätzung); 1991-96 Universitätsassistent am Forschungsinstitut für Europafragen der WU Wien; zahlreiche Publikationen im Bereich des Europarechts und der Verfassungspolitik der EU; 1994/95 Research Fellow an den Universities of Warwick and Essex (England); 1998/99 Gast- 
wissenschafter am Max-Planck-Institut für Gesellschaftsforschung in Köln; seit Sommer 1996 wissenschaftlicher Mitarbeiter des ITA hauptsächlich im Bereich Informations- und Kommunikationswissenschaften, insb. Internet; im März 2004 Habilitation in Wissenschafts- und Technikforschung an der Universität Wien. Seit Jänner 2006 Direktor des ITA.

KRISTÓF NYÍRI,

Towards a Philosophy of the Mobile Information Society

The mobile phone is not just the most successful machine ever invented, spreading with unheard-of speed; it is also a machine which corresponds to deep, primordial human communicational urges. The emergence of the mobile phone, far from being an insignificant event from the point of view of philosophy, forces the latter to reconsider a range of old issues, as well as to face a number of radically new ones. In fact the phenomenon of the mobile phone constitutes an obvious challenge to the humanities.

Worldwide, there were some 2.5 billion mobile phone users by August 2007. This figure, impressive enough by itself, reflects some fundamental conditions and changes. Combining the option of voice calls with text messaging, MMS, as well as e-mail, and on its way to becoming the natural interface through which to conduct shopping, banking, booking flights, and checking in, the mobile phone is obviously turning into the single unique instrument of mediated communication, mediating not just between people, but also between people and institutions, and indeed between people and the world of inanimate objects. Furthermore, the mobile is today emerging as the dominant medium in the sense of that strange singular in the plural, "media"- both as mass media and new media. The age group perhaps most deeply affected by the rise of the mobile is that of children. Ubiquitous communication fulfils a deeply human urge, and children especially suffer if deprived of the possibility of keeping in touch. Also, Dewey's observation that we need schools - artificial educational environments - because the young can no longer move around in the world of adults and thus learn spontaneously, by now appears to have once more become irrelevant. The medium in which the young play, communicate, and learn, is increasingly identical with the world in which adults communicate, work, do business, and seek entertainment. The mobile is clearly creating an organic learning environment.

The phrase "The Mobile Information Society" has been current since 1999 or so. However, one must increasingly come to realize that it is a mis- 
leading phrase. For mobile communications point to a future which offers a wealth of knowledge, not just of information, and promise to re-establish, within the life of modern society, some of the features formerly enjoyed by genuine local communities. "Community" on the one hand, "society" on the other, clearly differ in their connotations; it was Tönnies who, towards the end of the nineteenth century, crystallized this difference into a conceptual contrast. However, the striking observation in the recent literature on mobile telephony is that through constant communicative connectedness a kind of turning back to the living, personal interactions of earlier communities is brought about.

KRISTóf [J. C.] NyíRI, born 1944, is Professor of Philosophy at the Budapest University of Technology and Economics, Institute of Applied Pedagogy and Psychology. He is member of the Hungarian Academy of Sciences and of the Institut International de Philosophie. He was Leibniz Professor of the University of Leipzig for the winter term 2006/07. His main fields of research: the history of philosophy in the 19th and 20th centuries; the impact of communication technologies on the organization of ideas and society; the philosophy of images and the philosophy of time. Some main publications: Tradition and Individuality, Dordrecht: Kluwer, 1992; "Electronic Networking and the Unity of Knowledge", in Stephanie Kenna and Seamus Ross (eds.), Networking in the Humanities, London: Bowker-Saur, 1995; "The Concept of Knowledge in the Context of Electronic Networking", The Monist, July 1997; "The Picture Theory of Reason", in Berit Brogaard and Barry Smith (eds.), Rationality and Irrationality, Wien: öbv-hpt, 2001; Vernetztes Wissen: Philosophie im Zeitalter des Internets, Vienna: Passagen Verlag, 2004; "Time and Communication", in: F. Stadler and M. Stöltzner (eds.), Time and History, Frankfurt/M.: ontos verlag, 2006. Further information: www.hunfi.hu/nyiri. E-mail: nyiri.k@eik.bme.hu.

CLAUS PIAS,

Medienwissenschaft, Medientheorie oder Medienphilosophie?

Die Beschäftigung mit „Medien“ ist eine recht junge Erscheinung, die sich schnell und umfassend zu institutionalisieren vermochte. Für solche Neuerscheinungen gibt es durchaus historische Präzedenzfälle wie Informatik oder allgemeine Literaturwissenschaft. Unscharf bleiben trotz verschiedener Kanonisierungsunternehmungen jedoch Name, Programm und Gegenstand 
dessen, was als Medien-Wissenschaft, Medien-Theorie oder Medien-Philosophie summiert wird. Die Sache wird dadurch nicht einfacher, daß sich unter dem Druck drittmittelfähigen Antragsdesigns mittlerweile etliche inkompatible Forschungsansätze unter dem erfolgversprechenden Begriff „Medien“ versammeln. Zuletzt spielt (insbesondere im deutschsprachigen Raum) die Institutionengeschichte mit einer empirisch-sozialwissenschaftlichen Publizistik bzw. einer hermeneutisch-geisteswissenschaftlichen Film- und Fernsehwissenschaft eine erhebliche Rolle. Vor diesem Hintergund sollen fünf Thesen vorgestellt und diskutiert werden: 1. Es gibt keine Medien. 2. Medienwissenschaft ist keine Disziplin. 3. Medienwissenschaft ist eine Wissenschaft. 4. Medienwissenschaftler hätten Medienwissenschaft nicht erfinden können. 5. Medienwissenschaft ist nicht gleich Medienwissenschaft.

Claus Pias, Professor für Erkenntnistheorie und Philosophie der Digitalen Medien am Institut für Philosophie der Universität Wien. Studium der Elektrotechnik in Aachen, der Kunstgeschichte, Philosophie und Germanistik in Bonn und Bochum. Aktuelle Forschungsthemen und -projekte: Geschichte und Theorie der Computersimulation, Wissensgeschichte der Kybernetik, Skalierung als technisches und philosophisches Problem, Epistemologie des Kalten Krieges, Edition der kritischen Schriften Hermann Bahrs (18631934).

SIEGFRIED J. SCHMIDT,

Media Philosophy-A Reasonable Programme?

Über die wachsende Bedeutsamkeit von Medien in unserer Medienkulturgesellschaft gibt es weder im Wissenschafts- noch im Alltagsdiskurs ernsthaft Dissens. Wie in einer solchen Situation üblich, werden Medien und ihre Bedeutsamkeit zunehmend einer Selbst- wie einer Fremdbeobachtung unterzogen. Die Selbstbebachtung der Medien führt zu einer zunehmenden Selbstreferenz, aus der ganz praktisch Programm gemacht werden kann. Die Fremdbeobachtung haben einerseits empirisch orientierte Medien- und Kommunikationswissenschaftler, andererseits Philosophen übernommen. Während Medien- und Kommunikationswissenschaften seit langem disziplinär organisiert sind, kann bis heute von einer Medienphilosophie weder im Sinne eines festen Theoriegebäudes noch im Sinne einer etablierten Teildisziplin der Philosophie gesprochen werden.

Ein medienphilosophischer Ansatz konzentriert sich darauf, traditionelle 
philosophische Themen im Lichte der Wirksamkeit von Medien zu reformulieren. Die Liste der behandelten Themen ist sehr lang, sie reicht von Wirklichkeit, Wahrheit, Kultur, Gesellschaft, Erziehung und Politik bis zu Raum, Zeit, Gefühl, Subjekt und Unterhaltung.

Ein zweiter medienphilosophischer Ansatz konzentriert sich auf medienspezifische Themen wie Netzkultur, neue Sozialformen im Internet, Globalisierung, Wandel der Körperrelevanz, Wahrnehmungswandel, Spielkulturen oder Digitalisierung der Demokratie, wobei Überschneidungen mit den oben genannten traditionellen Themen unvermeidbar sind.

Diese Kurzcharakterisierung der thematischen Ebene impliziert m. E. auch eine Empfehlung für die Lösung der Organisationsfrage einer Medienphilosophie. Wenn sich die Themen aus argumentierbaren Gründen nicht randscharf voneinander trennen lassen, empfiehlt es sich, Medienphilosophie als notwendig interdisziplinär angelegtes Forschungsprogramm und nicht als traditionelle akademische Disziplin zu organisieren.

Alles wird darauf ankommen, als Beobachter 2. Ordnung Medienkompetenz zu entwickeln. Und dafür braucht es Medienphilosophie, die sich darüber klar ist, dass sie sich nur - in den Medien vollziehen kann, und zwar unter dem klaren Motto „Konstruktion und Kontingenz“.

Siegrried J. Schmidt, geb. 1940, Studium der Philosophie, Germanistik, Linguistik, Geschichte und Kunstgeschichte. o. Universitätsprofessuren in Bielefeld, Siegen und Münster. 2006 emeritiert von der Universität Münster.

URSULA SCHNEIDER,

Globalisierte Produktion von (akademischem) Wissenein Wettbewerbsspiel

Im Entdeckungszusammenhang der folgenden Überlegungen wirkt lebensweltliche Praxis, nämlich ein Unbehagen an den angeblich der Qualitätssicherung dienenden Ritualen der akademischen Praxis. Es wird die These aufgestellt, dass Ergebnisse in einem globalen Kontext unter Wettbewerbsbedingungen zunehmend industrialisiert generiert werden, wofür einiges an empirischer Evidenz ins Treffen geführt werden kann. Dieser Industrialisierungsprozess hat seine Wurzeln in einer Ausdifferenzierung zwischen und innerhalb von Disziplinen, im Gebrauch einer Weltsprache und einem Fokus auf Publikationsorganen aus dem angelsächsischen Forschungsraum, in der Digitalisierung, in der schieren Menge an Publikationen, in 
der „Audit Society“ (Power, 1997), die eine Obsession bezüglich Messung und Vergleich entwickelt hat. Letztere führt beobachtbar zu einer Zunahme von Betrug, Manipulation und Missbrauch, sowie zu einem erhöhten Maß an Selbstreferenz, welches die allgemein kausal interpretierten Korrelationen zwischen F\&E Ausgaben und Wirtschaftswachstum zumindest bezüglich sozialwissenschaftlicher Erkenntnisse fragwürdig werden lässt. Auf der Seite der Konsequenzen dieser Beobachtungen sind Mängel an Kreativität, Ästhetik, Eigen-Sinn, eine Abnahme lebensweltlicher Relevanz einerseits bzw. die nicht reflektierte Unterstützung von Herrschaft andererseits, sowie eine zunehmende Sprachlosigkeit innerhalb und zwischen Disziplinen näher zu untersuchen.

Ursula SchNeIDER ist nach Studien der Ökonomie und Pädagogik seit 1994 für das Institut für Internationales Management an der Karl-Franzens-Universität verantwortlich. Davor hat sie als Wirtschaftsprüferin und an Lehrstühlen in verschiedenen deutschen Bundesländern und den USA gearbeitet. Forschungs- und Lehraufenthalte haben sie ans College d'Europe, nach St. Gallen, Australien, USA, Indien, Thailand und Malaysien geführt, so dass sie unterschiedliche akademische Systeme kennen lernen konnte. Ihre Forschungsschwerpunkte sind Globalisierung, Wissensproduktion, Organisationstheorie und das Messen von Qualitäten. Sie hat einige Forschungspreise gewonnen und eine Vielzahl an Monographien und Aufsätzen publiziert. 
THE EDITORS

Herbert Hrachovec, born 1947, is associate professor of Philosophy at the University of Vienna and member of the University's academic senate. He has founded an electronic archive for philosophy texts and a repository for audio documents of a theoretical nature. For more detailed information see http://hrachovec.philo.at.

Alois Pichler, born 1966, is a member of staff at the Department of Culture, Language and Information Technology (AKSIS) at UNIFOB AS, Bergen, Norway. He is Director of the Wittgenstein Archives at the University of Bergen. He is member of the Executive Committee of the Austrian Ludwig Wittgenstein Society. Homepage: http://teksttek.aksis.uib.no/people/alois. 